Tarbawi: Jurnal Ilmu Pendidikan p-ISSN:1858-1080 | e-ISSN: 2615-6547

Vol. 16, No. 2, Desember 2020, 160 - 169

\title{
Learning the Concept of Absolute Value with Hawgent Dynamic Mathematics Software
}

\author{
Jerito Pereira ${ }^{1}$, Yongxing Huang ${ }^{1}$, Jihe Chen ${ }^{1}$, Neni Hermita ${ }^{2}$, Maximus Tamur ${ }^{3}$ \\ ${ }^{1}$ Guangxi Normal University, China \\ ${ }^{2}$ Universitas Riau, Indonesia \\ ${ }^{3}$ Universitas Santo Paulus Ruteng, Indonesia \\ e-mail: jeritopereira@gmail.com
}

\begin{abstract}
Understanding the concept is one aspect that is needed and must be owned by students in learning mathematics. This research aims to make learning media assisted by hawgent dynamic mathematics software on understanding the absolute value in grade 10 Senior high school to help teachers explain the concepts and assist students in finding and understanding the basic concepts of absolute value topic. The development model used in this research is ADDIE development model. ADDIE is an abridgment of Analyze, Design, Develop and Evaluation. Researchers the learning media Hawgent can help students to understand and find the concept of absolute value. Based on several aspects, clearly and attractively with an average of $78.9 \%$ in the excellent category. It is concluded that the development of learning media Hangent dynamic mathematics software can be used on the subject of understanding the concept of absolute value and with the help of this software it can help teachers explain the concept of absolute value and the students are also very interested in this ICT-based learning media. This conclusion is related to the validation results of media experts and material experts, where the validation results from media experts on the use of learning media are in good categories.
\end{abstract}

Keywords: Mathematics Learning, Mathematical Concept, Absolute V alue, Hawgent Dynamic Software

\begin{abstract}
ABSTRAK. Pemahaman konsep merupakan salah satu aspek yang sangat dibutukan dan harus dimiliki oleh siswa dalam pembelajaran matematika. Oleh karena itu, tujuan dari penelitian ini adalah membuat media pembelajaran berbantuan hawgent dynamic mathematics software pada materi pemahaman nilai mutlak pada SMA kelas 10 untuk membantu guru menerangkan konsep serta untuk membantu siswa dalam menemukan dan memahami konsep dasar pada materi pemahaman nilai mutlak. The development model used in this research is ADDIE development model. ADDIE is an abridgment of Analyze, Design, Develop and Evaluation. Siswa dan guru menganggap media pembelajaran Hawgent dynamic mathematics sebagai media yang dapat membantu untuk memahami dan menemukan konsep suatu materi berdasarkan beberapa aspek diatas dengan jelas dan menarik dengan rata-rata $78.9 \%$ dengan kategori baik. Disimpulkan bahwa pemgembangan media pembelajaran Hawgent dynamic mathematics software dapat digunakan pada pokok bahasan pemahaman konsep nilai mutlak dan dengan bantuan software ini dapat membantu guru menjelaskan konsep nilai mutlak dan pihak siswa juga sangat tertarik dengan media pembelajaran yang berbasis TIK ini. Kesimpulan ini dikaitkan hasil validasi dari ahli media dan ahli materi, dimana hasil validasi dari ahli media pada pengunaan media pembelajaran ini dengan kategori baik.
\end{abstract}

Kata kunci: Pembelajaran Matematika, Konsep Matematis, Nilai Mutlak, Hawgent Dynamic Software 


\section{INTRODUCTION}

Education is the most important for improving the quality of human resources so the people are required to continue to strive to learn (Dini, Wijaya, \& Sugandi, 2018), understand, and master various disciplines to be applied in all aspects of life (Chatmaneerungcharoen, 2019; Surya, Zulfah, Astuti, Marta, \& Wijaya, 2020), especially in the field of mathematics (Asamoah, 2019; Fitri, Sibuea, \& Handayani, 2019; Jafar, Budayasa, \& Juniati, 2018; Van den Heuvel-Panhuizen \& Drijvers, 2014). Because mathematics as the mother of all knowledge and plays an important role in the world of education, it is often very difficult for students to understand the concepts (Landry, 2010; Rohendi, Septian, \& Sutarno, 2018; Tabach \& Trgalová, 2020).

Understanding the concept is one aspect that is needed and must be possessed by students in learning mathematics (Badraeni et al., 2020; Cunhua, Ying, Qunzhuang, \& Wijaya, 2019; Hermita, Alpusari, Noviana, Kurniaman, \& Islami, 2020). Such as the learning principle recommended by the National Council of Teachers of Mathematics (NTCM) that, "student must learn mathematics with understanding, actively building new knowledge from experience and prior knowledge" (Siagian, 2016; States, 2013) which means learning mathematics students must learn with understanding and actively build on new knowledge from previous experiences and knowledge.

In Bloom taxonomy, students' understanding of the concept is essential and is the main goal of educational institutions in general (Caniglia \& Meadows, 2018; Heer, 2018). Therefore, we are required to strive to teach students well so that students understand the concepts of each mathematical topic in general and mathematics material well in particular. Furthermore, Learning mathematics is very difficult to understand, especially abstract material, which requires many methods to understand it (Earnest, Gonzales, \& Plant, 2018).

Previous researchers' results have identified several things that cause student errors when they solve mathematical problems. The teacher only teaches students with methods that are often used and repeatedly used without the help of ICT-based learning media (T T Wijaya et al., 2020; Zulnaidi, Oktavika, \& Hidayat, 2020), students often got difficulties, because the teacher does not explain the concept of the material on the subject being taught so that it creates difficulties in the process of understanding the concept of the topic (Duval, 2006).

Therefore, understanding mathematics concepts is one of the main steps students can prepare to receive and understand the next mathematical topics (T.T. Wijaya, Ying, \& Purnama, 2020a). One of the mathematical concepts that is difficult for students to understand is the concept of absolute value. Absolute value is taught in grade 10, Senior high school. Students in understanding absolute value must be able to understand the elements that build absolute value deeply. Absolute value is nothing but the distance of a number to zero on a real number line (Goleman et al., 2019; Moulidiantina, n.d.). This concept is very important because it is the basis for building several concepts in basic calculus on the subject of limits.

For this reason, students must be taught the concept in-depth so that these students have a complete understanding. Learning mathematics at the secondary education level, specifically the material for understanding the concept of absolute value, aims to make students understand the concept. Students can explain the relationship between the elements that build an understanding of the concept of absolute value and so that students can achieve the goals that have been formulated in the mathematics learning implementation plan.

The developments in information and communication technology in this era have brought very important benefits for human life sustainability. On this occasion, we can design mathematics learning media as a learning aid that can be used to encourage students to learn mathematics in understanding mathematics materials. ICT can also help teachers explain abstract mathematics material so that students can easily understand it (Habibi, Yusop, \& Razak, 2020; Pellegrino et al., 2014; Voithofer, Nelson, Han, \& Caines, 2019). 
Hawgent dynamic mathematic software is dynamic mathematical software with facilities to visualize or demonstrate mathematical concepts and construct mathematical concepts (T.T. Wijaya, Purnama, \& Tanuwijaya, 2020; T.T. Wijaya, Sukma, Purnama, \& Tanuwijaya, 2020). Based on the results of previous research, hawgent dynamic mathematics software has been proven to improve students' abilities and assist teachers in explaining the concept of a material (Chotimah, Wijaya, Aprianti, Akbar, \& Bernard, 2020; Tan, Zou, Wijaya, Suci, \& Dewi, 2020; T.T. Wijaya, Ying, \& Purnama, 2020b; Tommy Tanu Wijaya, 2021). Many studies have been conducted using hawgent, but most of these studies have been conducted on geometry and less research has been conducted on the topic of algebra or absolute value using hawgent.

Based on the background of understanding the concept above, the researcher tried to make learning media assisted by hawgent on understanding absolute value in senior high schools to help teachers explain the concepts and assist students in finding and understanding basic concepts material understanding absolute values.

\section{METHOD}

The development model used in this research is ADDIE development model. ADDIE is an abridgment of Analyze, Design, Develop and Evaluation (Sari, 2018; Sumardani, Putri, \& Sumardani, 2020; T.T. Wijaya, Ying, et al., 2020b). Below can be seen the ADDIE research development framework in Figure 1.

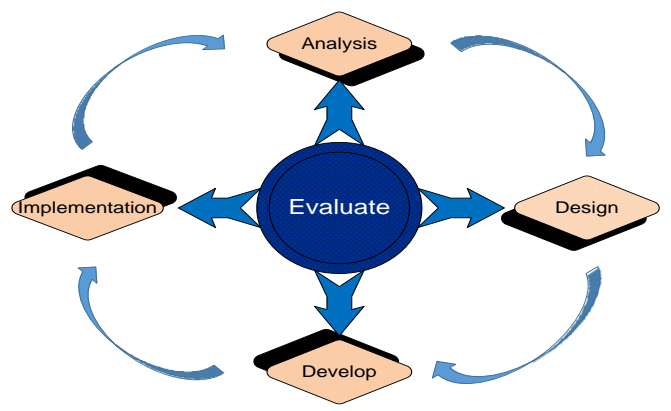

Figure 1. ADDIE model

1. Analyze

The main activities at this stage are several things that are the main points for analysis. First, to analyze students' difficulties in learning the subject of understanding the concept of absolute value (Bernard, Sumarna, Rolina, \& Akbar, 2019; T.T. Wijaya, Jianlan, \& Aditya, 2020). Second, analyzing the results of the former researchers on the same subject. The two main points of analysis are linked with methods that are often used and analyze the need to design innovative and creative learning methods and models to overcome these difficulties, it can be seen at the following stage.

2. Design

At design stage the researcher design ICT-based learning media based on the problems analyzed initially, designing the Hawgent Dynamic Mathematics Software learning media on the material of understanding the concept of absolute value. And in the next stage, compile the media validation instrument and material validation instrument by the media and material experts. The learning media can be seen in the Picture 2 . 

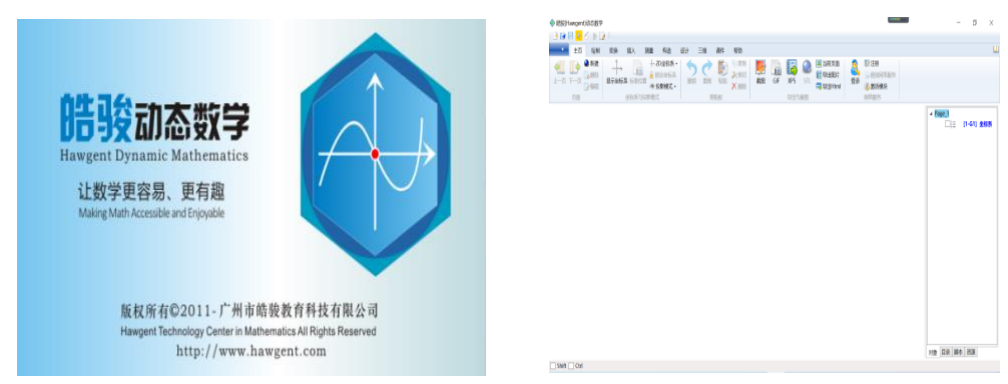

Figure 2. The pictures of learning media Hawgent Dynamic Mathematics Software

\section{Develop}

At the development stage, learning media on the topic of absolute value were validated by validator. In this study there are 3 professors from Guangxi Normal University and 4 experts from Indonesia. The results of validation can determine whether the learning media can be implemented or still requires revision. Learning media can be used after the researcher makes perfect revisions to the learning media.

\section{Implemetation}

In the implementation stage, the researcher implemented the design and methods that would be developed in real situations, namely in the classroom and observed the interactions between students and asked for feedback on the initial evaluation process from the students and teachers. In this study, the implementation was carried out in Indonesia by taking a SMA Putra Juang sample, Cianjur.

\section{Evaluation}

The evaluation stage is done at each stage to produce a perfect learning media product. This is the stage where the Hawgent Dynamic Mathematics Softwate learning media is being thoroughly tested through formative evaluation.

\section{RESULTS AND DISCUSSION}

\section{Analyze}

The evaluation stage is done at each stage to produce a perfect learning media product. This is the stage where the Hawgent Dynamic Mathematics Softwate learning media is being thoroughly tested through formative evaluation. At this analyze stage, there are two stages of analysis described by the researcher.

a. Statement of the teacher's difficulty when explaining the absolute value topic

The statement of the difficulties of teachers are, (1) the teacher lacks knowledge of ICTbased learning media so that they always use conventional methods that often neglect students in teaching and learning activities when teaching absolute value topic; (2) the teacher has very shortcomings in understanding the concept of absolute topic so it is difficult to find and explain the concept of absolute topic to students; (3), the teacher has never attended training on new learning media so that there is no ICT-based mathematics learning media used by the teacher to explain the concept of a material.

b. Statement of the teacher's difficulty when explaining the absolute value topic 
There are several difficulties the students have are: 1) students find it difficult to find and understand the concept of absolute value; 2) students often experience errors when working on questions about absolute value; 3) students feel very deficient in understanding the concept of the subject of understanding the concept of absolute value.

From some of the teachers 'and students' statements above, it can be concluded that many difficulties are often caused by a lack of knowledge about innovative learning media so that they often use conventional methods eventually result in student understanding of the conceptual understanding of a subject. Therefore, designing instructional media can help students and teachers in the teaching and learning process in the next stage.

\section{Design}

At this stage researchers design ICT-based learning media with Hawgent dynamic mathematics software as well as media creation steps with learning media story board that can be seen in Table 1.

Table 1. Learning Media Story Board

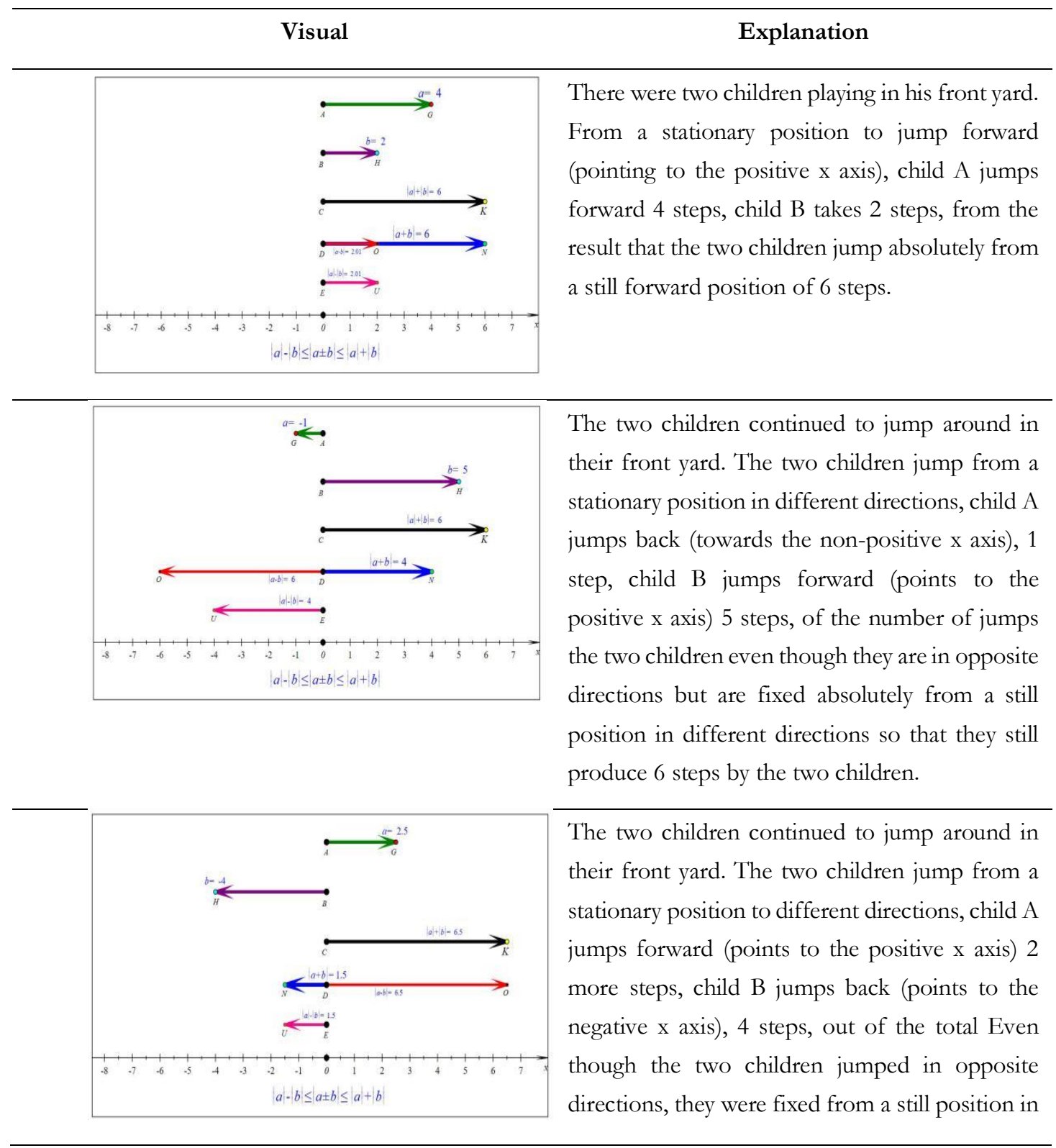




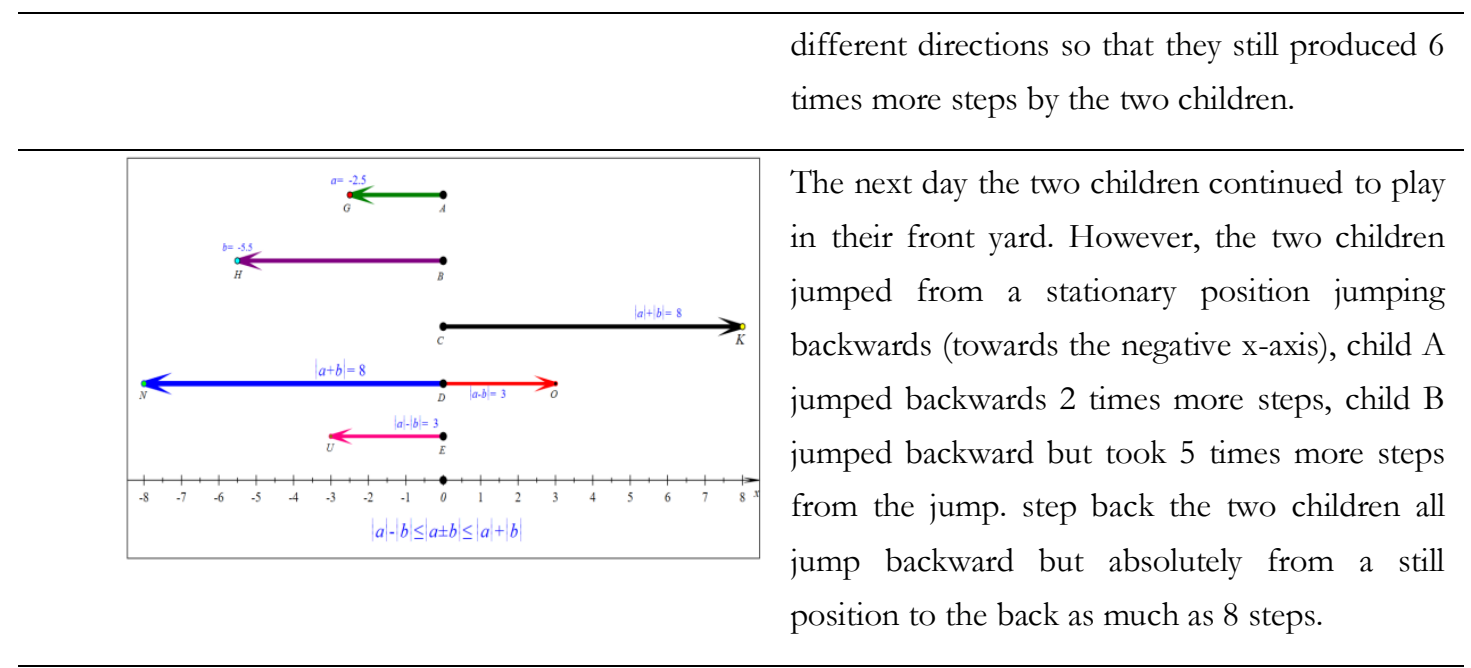

Conclusion, from the story of discovery and understanding of the concept with the help of Hawgent dynamic mathematical software based on Information Communication and Technology(ICT) above, it is concluded that from the jump results of the two children above even though jumping in opposite directions, stepping back (pointing to the positive $\mathrm{x}$ axis) and stepping back (leading to to the negative $\mathrm{x}$ axis), but it is still absolute from rest to how far you want to go.

3. Develop

3.1 Media expert validation data

Learning media is validated by 3 professors from Guangxi Normal university and 4 experts from SMA Negeri 2 Karawang. The results of learning media and material validation can be seen in Table 2. The advice of media and material experts assessment on learning media is to change Hawgent dynamic mathematics software's language to English. So that everyone can use it. From the validation results, it can be concluded that learning media can be implemented.

Table 2. The Result of Experts' Assessment

\begin{tabular}{cccl}
\hline Aspect & Score & Category & Conclusion \\
\hline Language & 7.8 & Good & Leaning media language worth a trial with a revision \\
\hline Text & 8.2 & Good & Leaning media text worth a trial without a revision \\
\hline Content & 7.4 & Good & Leaning materials can be motivating in learning absolute \\
\hline Design & 7.8 & Good & Leaning design worth a trial with a revision \\
\hline Animation & 8.3 & Good & Leaning media animation worth a trial with a revision \\
\hline Concept & 7.9 & Good & Learning concept worth a trial with a revision \\
\hline Curriculum & 8.6 & Very good & Leaning curriculum worth a trial without a revision \\
\hline
\end{tabular}

The evaluation stage is done at each stage to produce a perfect learning media product. This is the stage where the Hawgent Dynamic Mathematics Softwate learning media is being thoroughly tested through formative evaluation.

\section{Implemetation}

The following are some statements of students and teachers who are considered to be the result of implementing Hawgent Dynamic Mathematics Software learning media. So it can be more clearly seen in Table 3 . 
Tabel 3. Students and Teachers Statements in Using Hawgent Dynamic Mathematics Software

\begin{tabular}{cl}
\hline Aspect & \multicolumn{1}{c}{ Conclusion } \\
\hline Design & Agree that the learning materials easy to use and interesting \\
\hline Language & Agree that the language used is easy to understand \\
\hline Contents & Agree that leaning materials can be motivating in learning absolute \\
\hline Text & Agree that text of learning is clearly to understand \\
\hline Animation & Agree that animation of learning media is very attractive and interesting \\
\hline Concept & Agree that the language used is easy and simple to understand \\
\hline Curriculum & Agree that the according curriculum based learning is easy clearly
\end{tabular}

In table 3, it can be seen clearly that students and teachers consider the learning media of Hawgent as a learning media that can help student to understand and find the concept of absolute value based on the above aspects.

Based on the results of teachers and students' statements regarding the operation or use of the media, it is seen at the implementation stage. Where, students' statements in observing the explanation of the discovery and understanding of the concept of absolute value are very satisfying and very helpful for students while there are several statements from the teacher that learning media is very helpful for the teacher, therefore, it is concluded that the use of technology-based learning media is very practical which can use both teachers and students (Mushipe \& Ogbonnaya, 2019; Suan, Ying, \& Wijaya, 2020; Zhang, Zhou, \& Wijaya, 2020).

The results of this study compared to the results of previous study research on the same topic as using conventional methods, so the use of media learning is more than conventional methods because media learning has designs and animations that are interesting and very helpful to students understand the concept of a subject and also help teachers in explaining concepts to students, especially math lessons.

5. Evaluation

After the implementation stage of the Hawgent dynamic mathematics software learning media, there are some things that need to be evaluated like the stage of media learning design on the absolute value only use 2D system so it needs to be designed 3D system to be more interesting, and also has to make the video learning so that easy to access by students and teachers.

\section{CONCLUSION}

From several stages of using the method with the results and discussion, it can be concluded that the development of learning media Hawgent dynamic mathematics software can be used on the subject of understanding the concept of absolute value and with the help of this software it can help teachers explain the concept of absolute value and the students are also very interested in learning media based on this ICT. This conclusion is related to the validation results from media experts and material experts, where the validation results from media experts on the use of this learning media are in a sufficient category but need to be slightly revised and the validation results from material experts are also in a sufficient category and need a little revision as well so that in the future more feasible in its use. Based on the above conclusions, researchers recommended that each ICT-based media researcher be able to use this media in schools because this research is limited to creating or creating learning media.

\section{REFERENCES}

Asamoah, M. K. (2019). TPACKEA Model for Teaching and Students' Learning. Journal of Academic Ethics, 17(4), 401-421. https://doi.org/10.1007/s10805-019-09326-4 
Badraeni, N., Pamungkas, R. A., Hidayat, W., Rohaeti, E. E., Wijaya, T. T., Sudirman, J. J., \& Barat, J. (2020). Analisis kesulitan siswa berdasarkan kemampuan pemahaman matematik dalam mengerjakan soal pada materi bangun ruang sisi datar. Jumal Cendekia : Jurnal Pendidikan Matematika, 04(01), 247-253.

Bernard, M., Sumarna, A., Rolina, R., \& Akbar, P. (2019). Development of high school student work sheets using VBA for microsoft word trigonometry materials. Joumal of Physics: Conference Series, 1315(1). https://doi.org/10.1088/1742-6596/1315/1/012031

Caniglia, J., \& Meadows, M. (2018). An application of the Solo taxonomy to classify strategies used by preservice teachers to solve "One Question Problems." Australian Journal of Teacher Education, 43(9), 7589. https://doi.org/10.14221/ajte.2018v43n9.5

Chatmaneerungcharoen, S. (2019). Improving Thai Science Teachers' TPACK through an Innovative Continuing Professional Development Program. Journal of Physics: Conference Series, 1340(1). https://doi.org/10.1088/1742-6596/1340/1/012017

Chotimah, S., Wijaya, T. T., Aprianti, E., Akbar, P., \& Bernard, M. (2020). Increasing primary school students ' reasoning ability on the topic of plane geometry by using hawgent dynamic mathematics software Increasing primary school students ' reasoning ability on the topic of plane geometry by using hawgent dynamic mathematics. Journal of Physics: Conference Series, 1657(1), 012009. https://doi.org/10.1088/1742-6596/1657/1/012009

Cunhua, L., Ying, Z., Qunzhuang, O., \& Wijaya, T. T. (2019). Mathematics course design based on six questions cognitive theory using hawgent dynamic mathematic. Journal On Education, 02(01), 36-44.

Dini, M., Wijaya, T. T., \& Sugandi, A. I. (2018). Pengaruh Self Confidence Terhadap Kemampuan Pemahaman Matematik Siswa Smp. Jumal Silogisme, 3(1), 1-7.

Duval, R. (2006). A cognitive analysis of problems of comprehension in a learning of mathematics. Educational Studies in Mathematics, 61(1-2), 103-131. https://doi.org/10.1007/s10649-006-0400-z

Earnest, D., Gonzales, A. C., \& Plant, A. M. (2018). Time as a measure: Elementary students positioning the hands of an analog clock. Journal of Numerical Cognition, 4(1), 188-214. https://doi.org/10.5964/jnc.v4i1.94

Fitri, M., Sibuea, L., \& Handayani, M. (2019). Efektivitas Pengembangan Media Pembelajaran Monopoli Matematika (Monotika) Siswa. Jurnal Education and Development, 7(4), 41-48.

Goleman et al., 2019. (2019). Matematika Kelas X Buku Guru. In Journal of Chemical Information and Modeling (Vol. 53).

Habibi, A., Yusop, F. D., \& Razak, R. A. (2020). The role of TPACK in affecting pre-service language teachers' ICT integration during teaching practices: Indonesian context. Education and Information Technologies, 25(3), 1929-1949. https://doi.org/10.1007/s10639-019-10040-2

Heer, R. (2018). A model of learning objectives -based on A Taxonomy for Learning, Teaching, and Assessing: A revision of Bloom's Taxonomy of Educational Objectives. Contemporary Theories of Learning, 97-113.

Hermita, N., Alpusari, M., Noviana, E., Kurniaman, O., \& Islami, N. (2020). Profile of prospective primary school teachers' mental model in the subject matter of change. Joumal of Physics: Conference Series. https://doi.org/10.1088/1742-6596/1521/4/042096

Jafar, J., Budayasa, I. K., \& Juniati, D. (2018). Profile of Mathematics Education Students' Understanding with Moderate Mathematics Ability in the Aspect of Dissection of Group. Variabel, 1(1), 26. https://doi.org/10.26737/var.v1i1.514 
Landry, G. A. (2010). Creating and Validating an Instrument to Measure Middle School Mathematics Teachers' Technological Pedagogical Content Knowledge (TPACK). Doctoral Dissertation, 1-93.

Moulidiantina, L. (n.d.). Persamaan dan Pertidaksamaan Nilai Mutlak Linier Satu Variabel. Buku.

Mushipe, M., \& Ogbonnaya, U. I. (2019). Geogebra and Grade 9 learners' achievement in linear functions. International Journal of Emerging Technologies in Learning, 14(8), 206-219. https://doi.org/10.3991/ijet.v14i08.9581

Pellegrino, J. W., Wilson, M. R., Koenig, J. A., Beatty, A. S., Assessments, D., Testing, B., ... Sciences, S. (2014). Developing Assessments for the Next Generation Science Standards. In Developing Assessments for the Next Generation Science Standards. https://doi.org/10.17226/18409

Rohendi, D., Septian, S., \& Sutarno, H. (2018). The Use of Geometry Learning Media Based on Augmented Reality for Junior High School Students. IOP Conference Series: Materials Science and Engineering, 306(1). https://doi.org/10.1088/1757-899X/306/1/012029

Sari, I. P. (2018). Implementasi Model Addie Dan Kompetensi Kewirausahaan Dosen Terhadap Motivasi Wirausaha Mahasiswa. Jurnal Ekonomi Pendidikan Dan Kewirausahaan, 6(1), 83. https://doi.org/10.26740/jepk.v6n1.p83-94

Siagian, M. D. (2016). Kemampuan koneksi matematik dalam pembelajaran matematika. MES: Journal of Matematics Education and Science2, 2(1), 58-67.

States, N. L. (2013). Next Generation Science Standards: For States, By States. In Next Generation Science Standards: For States, By States (Vol. 1-2). https://doi.org/10.17226/18290

Suan, L., Ying, Z., \& Wijaya, T. T. (2020). Using hawgent dynamic mathematics software in teaching arithmetic operation. International Journal of Education and Learning, 2(1), 25-31. https://doi.org/10.31763/ijele.v2i1.97

Sumardani, D., Putri, A., \& Sumardani, N. I. (2020). E-Learning Utilizing Schoology: Teaching Theory of Relativity Using Online. Risenologi : Jurnal Sains, Teknologi, Sosial, Pendidikan, Dan Bahasa, 5(1), 48-55. https://doi.org/10.47028/j.risenologi.2020.51.75

Surya, Y. F., Zulfah, Astuti, Marta, R., \& Wijaya, T. T. (2020). The Development of Open-Ended Math Questions on Grade v Students of Elementary School. Journal of Physics: Conference Series, 1613(1). https://doi.org/10.1088/1742-6596/1613/1/012081

Tabach, M., \& Trgalová, J. (2020). Teaching Mathematics in the Digital Era: Standards and Beyond. STEM Teachers and Teaching in the Digital Era, 221-242. https://doi.org/10.1007/978-3-030-29396-3_12

Tan, S., Zou, L., Wijaya, T. T., Suci, N., \& Dewi, S. (2020). Improving student creative thinking ability with problem based learning approach using hawgent. Journal on Education, 02(04), 303-312.

Van den Heuvel-Panhuizen, M., \& Drijvers, P. (2014). Realistic Mathematics Education. In Encyclopedia of Mathematics Education. https://doi.org/10.1007/978-94-007-4978-8_170

Voithofer, R., Nelson, M. J., Han, G., \& Caines, A. (2019). Factors that influence TPACK adoption by teacher educators in the US. Educational Technology Research and Development, 67(6), 1427-1453. https://doi.org/10.1007/s11423-019-09652-9

Wijaya, T.T., Jianlan, T., \& Aditya, P. (2020). Developing an Interactive Mathematical Learning Media Based on the TPACK Framework Using the Hawgent Dynamic Mathematics Software. Emerging Technologies in Computing, 318-328. https://doi.org/10.1007/978-3-030-60036-5

Wijaya, T.T., Purnama, A., \& Tanuwijaya, H. (2020). Pengembangan Media Pembelajaran Berdasarkan Konsep Tpack pada Materi Garis dan Sudut Menggunakan Hawgent Dynamic Mathematics Software. 
JPMI - Jurnal Pembelajaran Matematika Inovatif, 3(3), 205-214. https://doi.org/10.22460/jpmi.v1i3.205214

Wijaya, T.T., Sukma, M., Purnama, A., \& Tanuwijaya, H. (2020). Pengembangan media pembelajaran berbasis tpack menggunakan hawgent dynamic mathematics software. Joumal of Elementary Education, 03(03), 64-72.

Wijaya, T.T., Ying, Z., \& Purnama, A. (2020a). The empirical research of hawgent dynamic mathematics technology integrated into teaching. Journal Cendekia: Jurnal Pendidikan Matematika, 04(01), 144-150.

Wijaya, T.T., Ying, Z., \& Purnama, A. (2020b). Using Hawgent dynamic mathematics software in teaching trigonometry. International Journal of Emerging Technologies in Learning, 15(10). https://doi.org/10.3991/ijet.v15i10.13099

Wijaya, T T, Ying, Z., Chotimah, S., Bernard, M., Zulfah, \& Astuti. (2020). Hawgent dynamic mathematic software as mathematics learning media for teaching quadratic functions. Joumal of Physics: Conference Series, 1592(1). https:// doi.org/10.1088/1742-6596/1592/1/012079

Wijaya, Tommy Tanu. (2021). How chinese students learn mathematics during the coronavirus pandemic. International Journal of Educational Research and Innovation (IJERI), 15, 1-16. https://doi.org/https://doi.org/10.46661/ijeri.4950

Zhang, X., Zhou, Y., \& Wijaya, T. T. (2020). Hawgent Dynamic Mathematics Software to Teach Line and Angle. JNPM (Jurnal Nasional Pendidikan Matematika), 4(2), 237-247.

Zulnaidi, H., Oktavika, E., \& Hidayat, R. (2020). Effect of use of GeoGebra on achievement of high school mathematics students. Education and Information Technologies, 25(1), 51-72. https://doi.org/10.1007/s10639-019-09899-y 